\title{
Gender and the Distribution of Wealth in Developing Countries
}

\section{Carmen Diana Deere ${ }^{1}$ and Cheryl R. Doss ${ }^{2}$}

October 2006

\begin{abstract}
Only recently has it been recognized that women may not share in the wealth of men, even within the same household or family. Moreover, there is growing evidence that the gender distribution of wealth matters. This paper first reviews the available evidence for developing countries on the gender asset gap and finds that it is significant. It then considers the constraints on women's asset ownership with particular attention to the role of legal marital and inheritance regimes. The paper then turns to a more detailed examination of women's land ownership in Latin America and Africa. The final section considers the impact of women's land ownership on household income and welfare.
\end{abstract}

Keywords: women, assets, gender inequality, marital regimes, inheritance, land, Latin America, Africa, law

JEL classification: J16, D31, P48, O13

Copyright (c) UNU-WIDER 2006

${ }^{1}$ Center for Latin American Studies, University of Florida; ${ }^{2}$ Yale Center for International and Area Studies.

This study has been prepared within the UNU-WIDER project on Personal Assets from a Global Perspective, directed by Jim Davies.

UNU-WIDER acknowledges with thanks the financial contributions to its research programme by the governments of Denmark (Royal Ministry of Foreign Affairs), Finland (Ministry for Foreign Affairs), Norway (Royal Ministry of Foreign Affairs), Sweden (Swedish International Development Cooperation Agency_Sida) and the United Kingdom (Department for International Development). 


\section{Acknowledgements}

The authors are grateful to Feminist Economics, and the journal's editor, Diana Strassman, for the opportunity that led to our collaboration. This paper is a further elaboration of Deere and Doss (2006) and the ideas in the special issue on Women and the Distribution of Wealth which we co-guest edited. The special issue was funded by a generous grant from The Ford Foundation. Catherine Vaughan provided research assistance on the section on land in Africa.

The World Institute for Development Economics Research (WIDER) was established by the United Nations University (UNU) as its first research and training centre and started work in Helsinki, Finland in 1985. The Institute undertakes applied research and policy analysis on structural changes affecting the developing and transitional economies, provides a forum for the advocacy of policies leading to robust, equitable and environmentally sustainable growth, and promotes capacity strengthening and training in the field of economic and social policy making. Work is carried out by staff researchers and visiting scholars in Helsinki and through networks of collabourating scholars and institutions around the world. www.wider.unu.edu publications@wider.unu.edu

UNU World Institute for Development Economics Research (UNU-WIDER)

Katajanokanlaituri 6 B, 00160 Helsinki, Finland

Camera-ready typescript prepared by Lorraine Telfer-Taivainen at UNU-WIDER

The views expressed in this publication are those of the author(s). Publication does not imply endorsement by the Institute or the United Nations University, nor by the programme/project sponsors, of any of the views expressed. 


\section{Introduction: why the distribution of wealth by gender matters}

It is well recognized that the ownership of assets improves the lives of the women and men who own and control them. The relationships between asset ownership and reduced poverty and enhanced security have been extensively researched, as has the relationship between asset accumulation and economic and political power. What has only recently garnered attention is that women may not share in the wealth of men, even within the same household or family. Women and men not only have significantly different access to wealth but also may use their assets and asset income differently, which may have consequences for household wellbeing as well as for the larger society. While the relationships are nuanced and complex, women's asset ownership is associated with their increased empowerment and individual wellbeing. To the extent that owning assets improves women's productivity and ability to earn a living, women's ownership of assets will contribute to economic growth and development. The evidence strongly supports the claim that the gender distribution of wealth is important. ${ }^{1}$

The first reason that the gender distribution of wealth matters is related to equity. If women systematically have less access to wealth, then the equity issues are similar for the distribution of wealth by gender as by race and ethnicity. The patterns of wealth ownership by gender worldwide suggest that women face greater constraints than men in accumulating and keeping assets.

Second, men and women may use wealth in different ways. This discrepancy can have effects that originate in the household but permeate the larger society. A large body of evidence suggests that the outcomes of household decisions depend on who has more bargaining power within the household. Since bargaining power is often measured as access to income or ownership of wealth, this suggests that the gender patterns of wealth ownership are important, even within households. Studies have shown that household expenditures differ depending on the assets brought to marriage by each spouse (Quisumbing and Maluccio 2003) and that the current asset distribution by gender affects household expenditure patterns on food, health, education and household services (Thomas 1999; Katz and Chamorro 2003; Doss 2006a). Women's asset ownership may increase the anthropemetric status of children (Duflo 2000) and the incidence of prenatal care (Beegle et al. 2001) and reduce domestic violence (Panda and Agarwal 2005; Friedemann-Sánchez 2006).

A third reason the gender distribution of wealth is important is the relationship between assets and poverty. Among the poor, wealth may be very limited, but the assets they own such as land, housing, small businesses, and even consumer durables may have an

1 This section is drawn from Deere and Doss (2006). 
important impact on their wellbeing. Incorporating gender into studies of wealth and poverty could also illuminate the ways gender intensifies or mitigates financial vulnerability during times of economic stress, when assets can provide a degree of security.

Lastly, asset ownership is related not only to wellbeing but also women's empowerment. Agarwal $(1994,1997)$ has argued forcefully that women's ownership of land leads to improvements in women's welfare, productivity, equality, and empowerment, a proposition that is gaining resonance among the international development community (World Bank 2001). Owning assets may give women additional bargaining power not just in the household, but also in their communities and other public arenas.

Additional empirical research is needed to demonstrate that women's ownership of assets is likely to keep them out of poverty or safe from destitution; lead to better outcomes for children such as increased school retention or higher expenditures on education and health; or result in better outcomes for women in case of separation, divorce, or widowhood. Since the same factors that influence women's ability to obtain and keep assets also influence their ability to negotiate other outcomes within the household, it is difficult to econometrically determine the causal relationships. But growing evidence, both econometric and qualitative, suggests that these relationships are present and that women's asset ownership is crucial for women's wellbeing.

\section{The gender asset gap: evidence from developing countries}

Not much is known about the distribution of wealth by gender in developing countries, particularly at the national level. In many countries, land is still the most important component of wealth, particularly in rural areas. The data on the gender asset gap in land for Latin America and Africa will be reviewed in sections 4 and 5. Here we summarize the few studies that shed light on the distribution of assets more broadly, highlighting gender differences in assets brought to marriage and in the composition of assets.

The extent to which women are able to accumulate assets prior to marriage varies enormously cross-culturally, depending on such practices as dowry, inheritance patterns, and women's labour force participation. Quisumbing and Maluccio (2003: table 1) analyzed recall data on assets brought to marriage in Bangladesh, Indonesia, Ethiopia, and South Africa. In all of these cases, husbands brought greater wealth to marriage than did wives. These differences were substantial, and the gender inequalities tended to persist over the life cycle. Breza (2005) examined data on assets brought to marriage by Hausa households in Northern Nigeria. Not only did men bring more assets to the marriage, but during the marriage they continued to accumulate wealth while women spent down their assets. 
Analyzing survey data for six developing countries, Quisumbing and Hallman (2003) found that while husband-wife gaps in age and education are closing, the distribution of assets at the time of marriage continues to favour husbands. The authors suggested that while the reduction of husband-wife gaps in schooling and age may improve the balance of power within the family, the persistent gender-asset gap in favour of husbands may impact family wellbeing.

Antonopoulos and Floro's (2005) study of low-income urban households in Bangkok, Thailand demonstrates the importance of asset ownership among the poor and the variations in the composition of assets according to gender. The survey they undertook in 2002 of married couples showed that the mean value of men's real assets only slightly exceeded that of women. Whereas women were more likely to own jewelry (an important and relatively liquid means of wealth accumulation in Asia), men were more likely to own transport vehicles. A higher proportion of women than men owned individual financial assets but the mean value reported was similar.

These micro-level studies provide some information about the distribution of particular assets in a given location, but there is scant data on the gender distribution of wealth at the national level, even for developed countries with good sources of national-level data (Deere and Doss 2006). There are a number of reasons for this. First, as discussed throughout this volume, there is considerably less information on wealth than on income. Second, researchers collect most of the data on wealth at the household rather than the individual level. Most analyses focus on variations in wealth by comparing characteristics of the household head: age, education, occupation, and sometimes gender. But analyses based on the gender of the household head do not tell us much about the distribution of wealth by gender overall. 2

Third, there are conceptual issues in sorting out who owns property within married couples. Marital property regimes define the legal ownership of assets brought to and acquired during the marriage, and these regimes differ radically, both across countries and within countries with a federal system. Furthermore, an individual's perceptions of ownership within marriage and social norms may not conform to legal norms. Rather than disentangling complex legal issues to determine who owns different assets within the household, economists tend to make the simplifying assumption that all assets are jointly owned.

A fourth issue is that the timing and composition of wealth transfers may differ crossculturally. In some places the majority of transfers take place at the time of marriage or as inter vivos transfers during marriage, while in other places bequests are more

2 Doss (2006b) demonstrates that in Ghana, using female-headed households underestimates the gender land gap, in comparison with analysis using individual landholdings. 
important. 3 Many studies focus on only one component of wealth, but sources in addition to types of wealth may be gender differentiated.

Fifth, the concept of ownership itself may be complex, especially in developing countries. Different individuals may have rights over the same animal or piece of land. For example, in some countries women own the crops but not the land on which they are grown (Gray and Kevane 1999). Ownership and control of an asset also may differ (Agarwal 1994; Deere and León 2001a; Fafchamps and Quisumbing 2002). Researchers often define the owner as the person who can sell the asset, but this may not be the only or even the most important dimension of ownership (Meinzen-Dick et al. 1997; Rocheleau and Edmunds 1997).

\section{Constraints on women's ownership of assets}

Women's ability to accumulate wealth is conditioned by the state, the family, the community, and the market. Through civil codes and property and family law, the state defines the parameters regarding the accumulation, control, and transmission of property. Legislation that defines and limits married women's property rights has historically excluded women from owning and controlling assets. Reforms of such legislation as well as those affecting inheritance regimes have facilitated women's accumulation of wealth. Beginning in the late nineteenth century, state legislation establishing state pension or social security systems and reforming agrarian laws have also impacted women's ability to accumulate and control assets.

Family and community norms regarding the accumulation and transmission of wealth are as important as the state in setting the contours for women's relationship to assets. These norms are particularly important in areas of the world where customary marital and inheritance systems still prevail and carry legal recognition. In addition, often a large gap exists between formal, legal norms and actual practice. Much more work is needed to understand how social norms interact with legal frameworks to affect women's accumulation of wealth.

Markets, particularly the labour market, also affect women's ability to accumulate assets since saving out of current income is a primary means of accumulating wealth. Women's lower wages and the gender division of labour within the labour market and between productive and reproductive labour affect women's ability to accumulate wealth. In addition, the historical development of particular markets, such as the financial market, have had important implications for the composition of savings and

3 See Quimbing et al. (2001) for an excellent discussion of how households allocate land and schooling to their children. 
wealth and the ability of women to accumulate assets. In this section we privilege legal frameworks, given their importance to comparative analyses.

\subsection{Legal marital regimes}

In broad strokes, marital regimes follow three general models: full community property, partial community property, and separation of property. In many countries, couples may accept the legal default regime or opt for a different one. Community property regimes have historically been associated with countries whose legal tradition derives from Roman law, such as southern Europe and Latin America. The distinguishing factor between full and partial community property is what happens to the ownership of property acquired prior to the marriage as well as to inheritances received during the marriage. While in full community property regimes all assets are pooled, partial community property recognizes as individual property the assets acquired prior to marriage or received as inheritances after marriage. In most partial community property regimes, the income generated by individual property, such as rents and interest, is also pooled. In addition, in full or partial community property regimes, upon dissolution of the marriage for whatever reason the community property is divided equally between the two spouses (or their estates).

The separation of property regime was initially associated with Islamic law, as it evolved in the Ottoman Empire in the fifteenth to nineteenth centuries. After the Married Women's Property Acts were passed in the US and England in the nineteenth century, the separation of property regime came to prevail throughout the British Empire. In this marital regime the assets acquired by each spouse prior to or during the marriage remain their individual property, including the earnings generated from this property and any individual earnings such as wages or salaries. If the union is dissolved, there is no community property to divide. Whether a surviving spouse has a claim on the assets of the deceased depends entirely on the inheritance regime; similarly, in the case of divorce, any claim on assets acquired during the marriage depends on the provisions of divorce legislation. The marital regime itself does not confer any property rights.

In both traditional Islamic and Roman law, married women had a legal personality and could own, inherit, and bequeath property. In contrast, under British common law prior to the Married Women's Property Acts married women were considered an extension of their husbands and did not have their own legal personality. Hence, the importance of these nineteenth century reforms in the US, the UK and throughout the British Empire (Deere and Doss 2006). 4

\footnotetext{
4 In a few countries, such as Lesotho and Swaziland, married women are still considered minors and can not be allocated or bequeathed land or make decisions about its use (Walker 2002).
} 
Married women under Islamic law had even greater control over their property than did women under Roman law, because they retained possession and management of whatever property they brought to or acquired during the marriage (Esposito 2001; Fay 1998). Under the default marital regime of partial community property in Spain and Hispanic America, married women lost the right to manage their individual and community assets during their marriage. Nonetheless, this marital regime was particularly favourable to married women for it implicitly recognized women's contribution to the formation of community property through their domestic labour. Women had a much stronger fall-back position than they did in countries of the common law or Islamic traditions. If the marriage ended for any reason, women retained their own individual property as well as half of the community property (Deere and León 2001a; 2005).

An important watershed in the consolidation of married women's property rights worldwide has been the UN Convention on the Elimination of All Forms of Discrimination against Women (CEDAW), which went into effect in 1981. The section on property rights stipulates that to end discrimination against women, women's rights to own, inherit, and administer property in their own names must be recognized. Moreover, the law requires 'the same rights for both spouses in respect of the ownership, acquisition, management, administration, enjoyment and disposition of property’ (United Nations 1980). As of 2005, the CEDAW had been ratified by 179 of the 185 UN member countries.

In Latin America, the signing of CEDAW has had profound effects. Most countries have reformed or adopted new national constitutions that explicitly guarantee equal rights to men and women. Most that had not already done so reformed their civil and family codes to end statutory discrimination against women in family matters. All but three Latin American countries now legally recognize the dual-headed household, where husbands and wives have equal responsibility for household representation and the management of community property (Deere and León 2001a). Nonetheless, everywhere in the region there is a disjuncture between women's formal equality before the law and real equality in the accumulation and management of assets.

In India, in contrast, the signing of CEDAW has not led to significant changes in married women's property rights. The Hindu Marriage Act of 1955 recognized the property each spouse brought to marriage as their own separate property, which each could individually manage and use. 5 This act was silent, however, about the property acquired during marriage. As Datta (2006) argues, this approach disadvantages wives, who upon divorce have no legal right to a share of the property acquired by their husbands during marriage, even though they may have contributed to these assets either

\footnotetext{
5 The Hindu Marriage Act of 1955 is thus similar to the 1882 Married Women’s Property Act in England.
} 
monetarily or through their domestic labour. During divorce proceedings, women are only entitled to maintenance and potentially to alimony, but this is at the discretion of a judge. In this context, state policies requiring joint titling of assets is a revolutionary change in married women's property rights, for widowed or divorced women become legally entitled to half of this jointly titled property.

Many African countries have passed formal legislation protecting women's property rights, but the property rights regimes for women in Africa are a combination of customary and legal systems including remnants of colonial law, modern constitutional law, traditional law, and in some cases, religious law (such as Islamic or Hindu). These systems entail overlapping and sometimes conflicting rules. For example, in Kenya there are five separate legal systems for marriage: civil, Christian, Islamic, Hindu, and customary. Each system has its own rules regarding women's property rights within marriage and inheritance (Human Rights Watch 2003). Thus, the rules for women's property ownership are fluid and, depending on the judge, could be used in combination to either advantage or disadvantage women.

In the contemporary literature on wealth accumulation, little attention has been given to differing marital regimes and little research has been undertaken comparing the impact of different marital regimes on women's accumulation of property. Holding all else constant, given women's disadvantage in the labour market, one would expect women to fare better in countries where the default marital regime was total or partial community of property than in those where separation of property prevails (Deere and León 2001a). 6

\subsection{Inheritance regimes}

The state plays a major role in the transmission of assets through its potential to limit testamentary freedom, rules governing intestate succession (when there is no will), and power to tax estates. The tremendous variation in legal inheritance regimes internationally is reflected, in broad strokes, in the differences among regimes derived from Roman, Islamic, and common law. This picture is further complicated because in many regions the state is not the only source of succession law. Customary law may overlap with civil law and inheritance systems may differ across religious and ethnic groups. Even in countries with one dominant legal tradition under a federal system of government, such as the US or Mexico, succession law varies at the state level. And inheritance may differ substantially in practice from the formal legal regime. Here we focus on formal, legal inheritance regimes and highlight five major differentiating factors relevant to the analysis of women's accumulation of wealth: the difference between partible versus impartible inheritance; the degree of testamentary freedom;

6 For example, in the United States (where the default marital regime varies by state), in the late nineteenth century it was recognized that widows fared much better in community property states than in common-law states where separation of property prevailed (Shammas et al. 1987). 
whether male and female children are treated equally; the inheritance rights of spouses; and the role of dowry and dower.

Impartible inheritance is usually associated with primogeniture, whereby the eldest son inherits all or most of his parent's assets. Daughters obviously fare better under partible inheritance regimes, where the parent's wealth may be divided. The best example of an impartible inheritance regime is the tradition of primogeniture and entailed estates that was dominant through the nineteenth century in England, whereby the eldest son inherited the entire estate. ${ }^{7}$ Another difference in legal inheritance regimes emerged with the rise of liberalism in the eighteenth and nineteenth centuries; some countries adopted full testamentary freedom and others retained the privileged role of necessary (or forced) heirs - those who could not be disinherited through wills-as derived from Roman law. By the eighteenth century in England, men and single women had the right to freely will their property, with the one requirement being that widows retained the use or income rights over one-third of their husband's real property (the dower). With independence, most former British colonies adopted testamentary freedom. In India, the Hindu Succession Act of 1956 established unrestricted testamentary freedom (Agarwal 1994). In Latin America, the countries most influenced by nineteenth century British and North American liberalism-Mexico and several in Central America-adopted testamentary freedom in the late nineteenth and early twentieth centuries (Deere and Léon 2005).

The system of necessary heirs derived from Roman law reigned in much of Europe and throughout Latin America until the late nineteenth century and is still the prevailing system in southern Europe and South America. In colonial Hispanic America, as in Spain, individuals were free to will only one-fifth of their estate; the remaining fourfifths were reserved for the children or descendants of the deceased, or, in their absence, the deceased's parents or ascendants. After independence, in a nod to testamentary freedom, in most of these countries these shares increased from one-fifth to one-fourth (Deere and León 2001a, 2005). Inheritance regimes based on restricted testamentary freedom and necessary heirs provide the potential for sons and daughters to receive equal treatment. If a parent wills the unrestricted portion to only one child, gender inequality may result; however, the degree of gender inequality that could be introduced due to parental preference is small compared to that possible in a regime of full testamentary freedom. In addition, in countries of the Roman law tradition if the deceased did not leave a will, both sons and daughters are in the first order of inheritance and are treated equally (Deere and León 2001a).

\footnotetext{
7 See the detailed comparison of the partible and impartible inheritance regimes in Europe and Africa by Platteau and Baland (2001).
} 
Islamic law is the primary exception to this pattern of gender equality in legal systems based on partible inheritance and necessary heirs. Under Islamic law generally only one-third of an estate can be willed freely. The remainder is destined for the deceased's children and other necessary heirs. Of this restricted portion, daughters are entitled only to one-half the share of sons. This same discrimination against daughters holds if the deceased died intestate (Fay 1998; Esposito 2001). 8

There is great variation cross-culturally in the treatment of spouses under intestate, although they are often in the first order of inheritance in countries with a separation of property marital regime. Under traditional Islamic law, husbands and wives were always in the first order of inheritance, but widows were in a less favourable position than widowers. While husbands were entitled to one-fourth of their deceased wives' estate, wives were entitled to only one-eigth of the estate of their deceased husband and in polygamous marriages, this small share was divided among all the wives (Esposito 2001). In India, under the Hindu Succession Act of 1956, the first order of inheritance includes sons, daughters, the widow or widower, and the parents of the deceased; however, there are a number of variations at the state level, particularly with respect to inheritance of land (Agarwal 1994).

The overall trend internationally has been towards reforms which favour spouses in inheritance matters, as well as equal treatment of widows and widowers. In the civil codes adopted after independence, Latin American countries began to include spouses among those who would inherit under intestate in the absence of children or parents, preferring widows and widowers over siblings. 9 In the late nineteenth century, a few countries began to include spouses, even in cases with surviving children or parents, in the first order of inheritance under intestate, dictating that spouses would inherit an equal share. A few countries-including Venezuela, Bolivia, and Argentina-went even further and included spouses as necessary heirs that could not be excluded from a will (Deere and León 2005). This change has placed spouses in a privileged position compared to children, since they are also automatically entitled to half of the community property when widowed.

In recent decades, there also have been attempts in Africa to improve the inheritance rights of widows. In Ghana, under customary law, there was separation of property, but wives did not inherit from their husbands. The Intestate Succession Law of 1985 provided that, in the subdivision of farms under intestate, wives receive a three-

\footnotetext{
8 See Agarwal (1994) on the differences between Sunni and Shia law with respect to inheritance by daughters.

9 Under Roman law, the ordering of legitimate heirs for intestate included children (or descendants), parents (or ascendants), siblings, and collateral kin up to the twelfth degree. In most countries where inheritance laws were derived from Roman law, spouses only inherited under intestate when there were no living blood kin presumably because they had property rights to half of the community property.
} 
sixteenth share, reserving nine-sixteenths for the children, one-eighth for the surviving parent(s), and only one-eighth to be distributed according to customary inheritance law (Fenrich and Higgins 2002). This reform was explicitly designed to protect widows and children.

Overlapping with marital and inheritance regimes is the incidence of dowry and dower, practices that have developed cross-culturally to endow women with property, generally, in recognition of their greater vulnerability. The difference between dowry and dower vary, but the most common pattern is for dowry to be given by a girl's parents at the time of her marriage either to her directly or to her husband and/or his family. Dower, in contrast, is usually given by the groom (and/or his family) to the bride either at the time of marriage or is to be provided to the wife in case of dissolution of the union, for whatever reason. Where dower differs from bride wealth (or bride price) is that the latter is usually paid to the bride's family by that of the groom, and is more of a form of compensation for losing a daughter's labour, than a form of protection for the bride.

Historically, the main way that young women brought assets to marriage has been via a dowry. The relationship between dowry and inheritance depends on the context. Under Roman law, where sons and daughters inherited equally from their parents, dowry was usually treated as an advance on inheritance. After the deaths of both parents, a final accounting would be rendered whereby a daughter's dowry was deducted from her total inheritance share. In other contexts, a dowry is given in lieu of inheritance, thereby releasing parents from any obligation to include daughters in a will.

In certain circumstances, such as colonial Latin America, the practice of dowry has been associated with women's enhanced marriage prospects, the greater stability of marriage, as well as with a better economic position in widowhood (Nazarri 1991). By the nineteenth century, however, the practice of dowry in most Latin American countries had dwindled, and in the new civil codes that were promulgated after independence dowry either disappeared or was no longer required of parents of means (Deere and León 2005).

The practice of dowry is different in India, where the payment does not go to the bride, but instead to the groom's parents. In India, the practice of dowry has been illegal since 1961, however, it continues and is becoming increasingly common in areas of the country where bride wealth had previously prevailed. According to Rao (2005) the introduction of dowry in one such area in southern India has led to enhanced son preference among parents, a reduction in the level of support that married daughters can claim from their natal kin, and a shift away from relatively egalitarian marriages. On the other hand, she notes that a woman married with a dowry-even if she does not control it-tends to have stronger bargaining power vis-à-vis her mother-in-law. 
In sum, the study of marital regimes and inheritance norms and practices is crucially important to understanding the constraints and possibilities for women's accumulation of wealth. The fact that individual inheritances by men and women who constitute a couple are rarely taken into account in current survey research is a problem, and such research leads at best to only partial analyses of the underlying dynamics of household wealth accumulation. To illustrate these propositions, we now analyze women's land ownership in Latin America and Africa.

\section{Women's land ownership in Latin America}

The gender asset gap in land in Latin America is substantial. As Table 1 shows, in the various national rural household surveys undertaken in the early 2000s the share of landowners who are female ranged from only 11 per cent (Brazil) to a high of 27 per cent (Paraguay). Women are not only less likely to own land than men, but female landowners tend to own less land than men. Household surveys for eight Latin American countries revealed that the mean amount of land owned by women was always less than that of men although only in Chile and Paraguay is the gender difference statistically significant (Deere and León 2003: table 5). Throughout Latin America, inheritance is much more important for women than for men as the principal means of land acquisition. As Table 2 shows, for the six countries for which data are available, although sons are the preferred heirs, a larger share of women acquired their land through inheritance than men. This implies that other forms of land acquisitionmarket purchases, allocations through land reform, or redistribution by peasant or indigenous communities_-are even more biased against women.

Table 1: Distribution of landowners by gender, Latin America, various years (\%)

\begin{tabular}{lcccc}
\hline Country/Year & Women & Men & Couple & Total \\
\hline Brazil (2000) & 11 & 89 & $\mathrm{Na}$ & $100 \mathrm{n}=39,904$ \\
Honduras (2001) & 26 & 74 & $\mathrm{Na}$ & $100 \mathrm{n}=808$ \\
Mexico (2002) & 22.4 & 77.6 & $\mathrm{Na}$ & $100 \mathrm{n}=2.9 \mathrm{~m}$ \\
Nicaragua (2000) & 22 & 78 & $\mathrm{Na}$ & $100 \mathrm{n}=2,474$ \\
Paraguay (2001) & 27 & 69.6 & 3.2 & $100 \mathrm{n}=1,694$ \\
Peru (2000) & 12.7 & 74.4 & 12.8 & $100 \mathrm{n}=1,923$ \\
\hline
\end{tabular}

Sources: For Brazil, Mexico, Paraguay and Peru, Deere and León (2003: table 1); for Honduras and Nicaragua, Katz and Chamorro (2003).

Deere et al. (2005) hypothesize that female land ownership is positively associated with whether a woman's parents were landowners; the amount of land they owned; the gender composition of a woman's siblings (with those without brothers being more likely to inherit land); age; widowhood; household headship; and education. Women with more education should be able to defend their potential land rights more successfully; in addition, education serves as a proxy for labour market opportunities and hence the possibility of purchasing land independently. In countries with full or 
partial community property marital regime, marriage should also increase the likelihood of women acquiring land through the market, for if the couple buys land it legally pertains to both of them. Although they lacked data on a number of crucial variables, such as the landholdings of a woman's parents, Deere et al. (2005: table 4) estimated a Logit model of the determinants of female land rights. They found that for both Paraguay and Peru, whether the adult woman in the household has land rights was positively and significantly associated with female headship and a woman's age.

Katz and Chamorro (2003) explored the determinants of the total amount of land owned by women in Honduras and Nicaragua. They found that a woman's age, education and headship were all positively and significantly related to the amount of land they owned. The land area owned by the parents of the woman or her husband were not significant in explaining women's land ownership. Further work on the determinants of women's land rights will have to await the elabouration of household surveys with more appropriate data.

Table 2: Form of acquisition of land by gender, Latin America (\%)

\begin{tabular}{lccccccc}
\hline Country & Inheritance & Community & State & Market & Other & Total & \\
\hline $\begin{array}{l}\text { Brazil } \\
\text { women }\end{array}$ & 54.2 & - & 0.6 & 37.4 & 7.8 & 100 & $\mathrm{n}=4,345$ \\
men & 22.0 & - & 1.0 & 73.1 & 3.9 & 100 & $\mathrm{n}=34,593$ \\
Chile & & & & & & & \\
women & 84.1 & - & 1.9 & 8.1 & 5.9 & 100 & $\mathrm{n}=271$ \\
men & 65.4 & - & 2.7 & 25.1 & 6.8 & 100 & $\mathrm{n}=411$ \\
Honduras & & & & & & & \\
women & 39.7 & - & 0.7 & 57.4 & 2.2 & 100 & $\mathrm{n}=210$ \\
men & 19.1 & - & 0.7 & 77.9 & 1.4 & 100 & $\mathrm{n}=-$ \\
Mexico & & & & & & & \\
women & 81.1 & 1.8 & 5.3 & 8.1 & 3.7 & 100 & $\mathrm{n}=497$ \\
men & 44.7 & 14.8 & 19.6 & 12.0 & 8.9 & 100 & $\mathrm{n}=2,547$ \\
Nicaragua & & & & & & & \\
women & 37.2 & - & 15.2 & 46.9 & 0.4 & 100 & $\mathrm{n}=544$ \\
men & 21.6 & - & 16.8 & 61.0 & 0.4 & 100 & $\mathrm{n}=-$ \\
$\begin{array}{l}\text { Peru } \\
\text { women }\end{array}$ & 75.2 & 1.9 & 5.2 & 16.4 & 1.3 & 100 & $\mathrm{n}=310$ \\
men & 48.7 & 6.3 & 12.4 & 26.6 & 6.0 & 100 & $\mathrm{n}=1,512$ \\
couple & 37.3 & 1.6 & 7.7 & 52.6 & 0.8 & 100 & $\mathrm{n}=247$ \\
\hline
\end{tabular}

Sources: For Brazil, Chile, Mexico, and Peru, Deere and León (2003: table 1); for Honduras and Nicaragua, Katz and Chamorro (2003). 
Finally, note should be made of two recent trends in Latin America that may mitigate the gender asset gap in land: a growing trend towards gender equality in inheritance of land in certain countries and increasing state attention to gender concerns in land redistribution and titling programs. Deere and León (2003: 933) in their review of the literature on gender and land inheritance in twelve countries, found the following factors causally associated with a trend toward more gender equality in land inheritance: (i) rising literacy, including legal literacy, which is associated with a greater knowledge of national laws favouring equality of inheritance shares among children and/or the property rights of widows; (ii) a move toward partible inheritance practices, which is associated with smaller family size in rural areas; (iii) greater emigration from rural areas by children of both sexes, which is associated with fewer potential heirs interested in remaining in farming activities; and (iv) growing land scarcity and/or a decline in peasant agriculture, which is associated with a decreasing reliance by households on farming as their primary income-generating activity. Quantitative studies are nonetheless needed to confirm the relative importance of these trends.

The other major development of the last several decades has been the growing commitment by Latin American states to gender equity, reflected in the new land laws of the 1990s. As the agrarian reform legislation of the past was swept away by neoliberal land legislation, in many countries the legal figure of the male head of household as the beneficiary of state land redistribution efforts was replaced either by more gender neutral language, or in the more progressive cases, by a focus on the dualheaded household (where both adults are present) as the beneficiary of state efforts in land titling programs. As a result, the share of women beneficiaries, both individually and as a result of the joint titling of land to couples, has risen considerably (Deere and León 2001b). While there are indications that the distribution of land by gender is gradually becoming more equitable, the gender asset gap in land remains large and a source of concern.

\section{Women's land ownership in Africa}

Data on land rights in Africa is less available than for other regions of the world and that on women's land rights is even scarcer. In part, this lack of data on land rights is due to the fact that much land in Africa is untitled and held collectively. In Southern and Eastern Africa, for example, the amount of rural land that is privately owned ranges from 5 per cent in Lesotho to 67.5 per cent in South Africa (Walker 2002). Within the categories of private, communal and state-owned land are a range of overlapping rights to land that add layers of complexity to any analysis of land 'ownership' in Africa. For example, the Botswana Tribal Land Act includes and distinguishes between the rights of avail and of way, and the rights to occupy, use, have access to, transact, and exclude (Adams 2003). For Ghana, Goldstein and Udry (2005: 5) note 
Individual claims over land overlap. Who ends up farming a specific plot is the outcome of a complex, sometimes contentious, process of negotiation... The act of cultivating a given plot may, or may not, be associated as well with the right to the produce of trees on the land, the right to lend the plot to a family member, the right to rent out the land, the right to make improvements, or the right to pass cultivation rights to one's heirs.

Thus, the ability to farm the land, security of tenure, and the right to bequeath land does not necessarily depend on formal ownership in the sense of the land being individually titled. But it becomes much more difficult to sort out the meaning of land ownership in these contexts.

The limited data do suggest that the gender gap in land ownership in Africa is substantial. In Cameroon less than 10 per cent of the title deeds correspond to women (ICRW 2005) and in Kenya only 5 per cent of women own land in their own names. In Uganda only 7 per cent of women own land themselves (Rugadya et al. 2005). A FAO study (1997) finds that for a number of countries, women have smaller landholdings than men and are less likely to have any landholdings (see Table 3). Doss (2006a) found that women held land in only 10 per cent of Ghanaian households while men held land in 16-23 per cent. The mean value of men's land holdings was almost three times the mean value of women's landholdings. Although women were more likely than men to own business assets, the mean value of business assets owned by men was much higher than that owned by women. Thus, ownership of businesses does not compensate for the lack of land.

Table 3: Women's share of landholdings in selected African countries

\begin{tabular}{lrrr}
\hline & $\begin{array}{r}\text { Women's land as \% } \\
\text { of total agricultural } \\
\text { holdings }\end{array}$ & $\begin{array}{r}\text { Average size } \\
\text { women's holdings } \\
(\mathrm{HA})\end{array}$ & $\begin{array}{r}\text { Average size } \\
\text { men's holdings } \\
(\mathrm{HA})\end{array}$ \\
\hline Benin & 11 & 0.98 & 1.76 \\
Congo & 25 & 0.5 & \\
Morocco & 14 & 0.53 & 0.73 \\
Tanzania & 25 & & \\
Zimbabwe & & 1.86 & 2.73 \\
small-scale commercial & 3 & & \\
Zimbabwe & & & \\
large-scale commercial & 10 & & \\
\hline
\end{tabular}

Source: FAO (1997).

Land is acquired through marriage, inheritance, the market, the state, and through local community leaders. In Africa, local leaders often control the final allocations and can reallocate land as they deem necessary. Purchases of land comprise a relatively limited means of obtaining land, although this is changing. In some areas, rental markets 
provide access to land, without providing security of tenure. The challenge in understanding these patterns is that most legal systems in Africa are a combination of several legal systems, including civil and customary law, and some cases religious law. Customary law varies within individual countries in ways that may or may not coincide with state or regional boundaries. In general, however, the most common way that women gain access to land is through marriage. These rights may either be use rights, where the land is allocated to her by her husband, or permanent rights. In effect, most marital regimes are separation of property regimes, where men and women hold their property separately and women have little or no permanent claim on the property owned by their husbands. Thus, although women gain access to land through their husbands, they do not gain ownership of it. The distinction is important. Their claims to this land usually do not extend beyond the marriage, so that they lose the land in cases of death or divorce. In a survey in Nigeria, women distinguished between land that they owned themselves and land that was given to them by their husbands, with the former being the most secure form of access. Fifty-three per cent of land was obtained through their husbands, while they themselves owned only 4 per cent of the farmland (FAO 1997).

The inheritance patterns in Africa are complex, again with overlapping customary and legal regimes. Given that few countries have community property regimes and husbands and wives do not jointly own land, inheritance practices are particularly important for women. Yet widows do not necessarily inherit. This may result in a widow being evicted from the house that she shared with her husband and losing access to the land that they farmed.

There is no clear relationship between the lineage system-whether it is matrilineal or patrilineal-and women's access to land. In Malawi, if the marriage is patrilineal, as is common in the north, land inheritance is through male lineage; women can only access land through their husbands and sons. Even if the marriage is matrilineal, in situations where it is common for a woman to move to her husband's village, widows are likely to experience land insecurity. In situations where it is common for a man to move to his wife's village, women fare better, although the land is often really under the control of the wife's brothers or uncles (Shawa 2002). Yet in some areas in Malawi, Zambia and Mozambique, matrilineal and matrilocal systems result in land being passed both through the female blood lines and directly to women (Roth 2002).

The Akan in Ghana practice uterine matrilineal inheritance, where land is transferred from the deceased man to his brother or nephew. Under customary law, women do not inherit from their husbands. The 1985 Intestate Succession Law does provide for wives to inherit, but it has had limited impact in practice (Fenrich and Higgins 2002), Women in Ghana tend to fare better under the patrilineal systems, where a man's children inherit his land. They are more likely to support their mother, the widow, than is the deceased husband's brother or nephew. The changes in the laws in Ghana have had limited impact on actual inheritance practices. 
In Zambia, Munalula and Mwenda (1995: 93-100) report that recent statutory laws provide legal protection to widows, either by allowing a husband to make a will declaring the nature of his wife's or wives' inheritance, or through the intestate Succession Act of 1989 that permits a widow a 20 per cent share of her husband's property. Women's inheritance rights do not eliminate the gender gap. For example, in Ethiopia, one study found that the mean value of land inherited by husbands was ten times greater than that inherited by wives. Wives generally inherited land from either a previous husband or his family, rather than from their own parents (Fafchamps and Quisumbing 2002: 58-9). In Ghana, daughters frequently inherit less than their brothers, especially where land is scarce.

The marriage and inheritance systems interact in complex ways. The practice where a widow is inherited by her deceased husband's brother is widespread in some areas (Human Rights Watch 2003). This practice suggests that widows may have some claim to land when their husband dies, even if the claim is tenuous, because men use this practice to claim a greater proportion of their deceased brother's land. In some instances, the state owns and allocates the land. State land redistribution offers an opportunity for women to gain access to land, but their ability to take advantage of this opportunity varies. A survey of couples in Zimbabwe found that 98 per cent of resettlement area permits given for farming and grazing land were held by husbands, with only 2 per cent held by wives (Ikdahl 2005). Women lost their rights to stay on the settlement scheme once they were divorced, but there is some suggestion that they were allowed to remain if they were widowed. In Ethiopia's recent land titling process, women have been given access to formal land titles. As of October 2004, there were 721,978 land holdings registered. Of these 28.9 per cent were registered to women; 32.5 per cent were registered to men, and 38.6 per cent were jointly registered to a couple. The remaining land was registered as communal, or belonging to an NGO or governmental organization (Teklu 2005).

Many states in Africa have recently passed family and land bills that strengthen women's land rights. These are part of a wider effort to redistribute land and increase the security of tenure. Yet, numerous researchers have documented situations in which women have legal access to land, but they are unable to take advantage of this. For example, Tekle (2001) documents that in Eritrea, women have legal access to land, but it does not match the reality on the ground. The laws are in conflict with custom and many people are ignorant of the laws. In South Africa, the court ruled in 2004 that primogeniture was unconstitutional, but this information has not yet had an effect on customary land transfer (Ikdahl 2005). In other cases, although gender-equity laws are on the books, there is no pretense that they will be enforced. In Uganda, the State Minister for Lands, Baguma Isoke, described the Land Act as a literature document of no legal consequence (Okore 2006). Women’s rights also depend on land availability. In Sudano-Sahelian West Africa, where women usually have limited rights to cultivate on their own-account, growing land scarcity and concentration are shrinking their 
allotments (Gray and Kevane 1999). In Tanzania, in colonial times, land, unlike livestock, could pass from parents to daughters or sons; as populations increased, there was less land available, and women could inherit land from their parents only when their brothers 'had enough'. In some cases, female-owned land was taken back by their male relatives (Yngstrom 2002).

\section{The impact of women's land ownership on household income and welfare}

Access to land is important for both men and women. The lack of secure tenure, whether with legal titles or customary rules, limits land use options and the crops that will be grown on the land. In particular, it encourages farmers to plant annual crops rather than tree crops and to make limited investments in the land itself. 10 These factors are gendered to the extent that women's tenure is less secure than men's. In addition, lack of access to land is correlated with poverty. The lack of women's land ownership feeds into the system whereby women are not seen as real farmers. This, in turn, limits their access to credit, extension services, and access to other inputs. This can be an endless cycle whereby women are not given land because they are seen as less productive and they are less productive because they have less access to land and other inputs.

Deere et al. (2005) explore whether female land rights lead to higher rural household incomes in landowning households in Paraguay and Peru. Table 4 summarizes their results with respect to total net income, farm income and off-farm income, and three gender variables: households with female land rights, self-declared female-headed households, and households with no adult male. Model 1 includes all landed households, whereas Model 2 includes only dual-headed households, where both an adult male and female are present. Controlling for household and farm characteristics and regional factors, female land rights have different effects in the two countries. In Paraguay they are negatively related to total household income, with only the dummy for households without a male having a positive and significant impact. In contrast, in Peru female land rights are positively and significantly associated with higher total household income. While female land rights are negatively associated with farm income levels in both countries, in both, they are positively associated with off-farm income.

In Peru, where the agrarian structure is relatively egalitarian, with most farms being small, female land rights, evaluated at the mean, increase off-farm income by 400 per cent and net total household income by 47 per cent. Most interesting is that female land rights are positively and significantly associated with higher off-farm income only in dual-headed households (where both adults are present).

10 Although in some places, such as Ghana, planting tree crops increases one’s security of tenure. 
Table 4: Impact of gender variables on rural household incomes among landowning families

\begin{tabular}{|l|c|c|c|c|}
\hline & PARAGUAY & & PERU & \\
\hline & $\begin{array}{c}\text { Model 1 } \\
\text { All households }\end{array}$ & $\begin{array}{c}\text { Model 2 } \\
\text { Dual headed Only }\end{array}$ & $\begin{array}{c}\text { Model 1 } \\
\text { All households }\end{array}$ & $\begin{array}{c}\text { Model 2 } \\
\text { Dual headed Only }\end{array}$ \\
\hline Net household income & negative & negative & positive & positive \\
\hline female land & negative & & negative & \\
\hline female head & positive* & & negative & \\
\hline no male & negative* & negative & negative & negative \\
\hline Farm income & negative & & negative & \\
\hline female land & negative & & positive & \\
\hline female head & positive & positive & positive & positive \\
\hline no male & negative & & negative & \\
\hline Off-farm income & positive & & negative & \\
\hline female land & & & & \\
\hline female head & & & & \\
\hline no male & & & & \\
\hline
\end{tabular}

Note: *significant at 90\% level; **significant at 95\% level; ***significant at $99 \%$ level.

Source: Deere et al. (2005).

Mardon (2005) analyzes the impact of female land rights and collective action on intrahousehold bargaining power in the Brazilian agrarian reform. Focusing on dualheaded households on agrarian reform settlements in six states, she finds that holding individual and household characteristics constant, women's land rights are associated with higher rates of autonomous decision-making. She also finds that women's participation in the social movements which coordinate economic and political collective action contribute to women's voice. Women's membership in the Landless Rural Worker's Movement (MST) is associated with higher rates in joint household decision-making.

Katz and Chamorro (2003) suggest that in Honduras and Nicaragua there is a positive correlation between women's property rights and their overall role in the household economy. In Nicaragua, women with land rights in male-headed households tend to administer a greater share of crop and livestock income compared to those with no land rights. In Honduras, women with land rights in male-headed households generate a larger share of household income via their own 'microenterprises' than do women without land rights. In both countries, women with land rights contribute relatively more to the household through their own wage and salary income and are more likely to have received credit. Katz and Chamorro explore the impact of female land rights on the share of household expenditure on foodstuffs and the schooling attainment of children. Controlling for the level of corn production, household characteristics, household income and women's income as well as regional effects, they found that the amount of land owned by women as well as female household headship was positively and 
significantly related to the share of household expenditures on foodstuffs. In Honduras, but not Nicaragua, the level of female income was also positively and significantly associated with food expenditures (see Table 5). Evaluated at the mean, households with female land rights in Nicaragua spend 5.5 per cent more on foodstuffs than households without female land rights. In Honduras, 2.5 per cent more is spent on food. Female land rights had a small positive impact on children's schooling. Controlling for the gender of the child, average age, assets, headship, parents' education, share of farm income and distance to a primary school, and evaluated at the mean, children in households with female land rights complete 0.10 years of school more than in households without them. In both countries, children in female-headed households finish one year less of school.

Table 5: Impact of gender variables on family welfare

\begin{tabular}{|c|c|c|}
\hline & HONDURAS & NICARAGUA \\
\hline \multicolumn{3}{|c|}{ Share of food expenditures } \\
\hline female land & positive ${ }^{\star \star \star}$ & positive ${ }^{\star \star \star}$ \\
\hline female head & negative ${ }^{\star \star \star}$ & negative ${ }^{\star \star \star}$ \\
\hline female income & positive ${ }^{\star \star \star}$ & negative \\
\hline \multicolumn{3}{|c|}{ Child schooling } \\
\hline female land & positive ${ }^{\star \star *}$ & positive ${ }^{\star \star \star}$ \\
\hline female head & negative $^{\star \star \star}$ & negative ${ }^{\star \star \star}$ \\
\hline
\end{tabular}

Note: *significant at 90\% level; **significant at 95\% level; ***significant at 99\% level.

Source: Katz and Chamorro (2003).

Mardon (2005) also investigates children's school enrollment and attainment rates on Brazilian agrarian reform land settlements. Children progress more rapidly through school in lone mother beneficiary households, compared with those in dual-headed households. This suggests that that, given equal access to community resources, lone mothers invest more in their children's human capital. She concludes that the explicit bias in the agrarian reform policy towards dual-headed households may limit the potential social benefits. This analysis highlights the importance of considering the combined impact of female land rights and household composition and headship.

The impact of women's landholdings has similar effects on women's bargaining power as women's ownership of other assets. Using nationally representative data from Ghana, Doss (2006a) finds that the share of farmland held by rural women impacts household expenditures patterns. In 1991/92, women's share of farmland significantly increased budget shares on food and education and decreased budget shares on alcohol and tobacco, household durables, and household non-durables. In 1998/99, women's share of farmland significantly increased budget shares on food and decreased budget shares on household durables, household non-durables, clothing and the miscellaneous category. Using econometric analyses to examine the issues of the impact of land ownership on women's wellbeing is particularly fraught with endogeneity issues. The 
same factors may allow women access to land and improve their wellbeing; thus, it is difficult to demonstrate that it is necessarily the impact of land ownership that impacts upon women's wellbeing. Women throughout rural areas frequently claim that that their lack of access to land hinders their ability to support themselves and their children, suggesting that land is important to women's welfare.

Owning assets may even be a matter of life and death. Research, especially that coming out of Africa, is beginning to highlight the relationship between asset ownership and HIV/AIDS. Scholars suggest that the relationship between HIV/AIDS and wealth may go in both directions. A lack of assets may make women more vulnerable to AIDS, and contracting HIV/AIDS frequently means that women lose access to any property that they had (Strickland 2004). In addition, women's insecure property rights mean that they lose control of their property - and thus their sources of livelihood and securityonce their husband dies of AIDS.

\section{Conclusion}

Considerable progress has been made in measuring the distribution of wealth by gender and in understanding the factors that account for the gender wealth gap and why it matters. Although formidable methodological and data gaps make comparative work challenging, the evidence strongly suggests that it is critical to understand the gender patterns of wealth distribution in order to understand the dynamic patterns of wealth accumulation and distribution both within and across countries. Excluding gender from the analysis may lead to only partial understandings of the full distribution of wealth. Since household wealth may not belong jointly to the husband and wife, gender inequality within households biases estimates of the degree of wealth inequality in a given country. At the very least, and only as a first approximation of the gender asset gap, it is important to consider the gender of the household head in analyses of wealth inequality. More precise estimates, however, of the distribution of wealth will require measures of asset inequality at the individual as well as the household level.

Comparative work has been stymied until recently not only by the lack of comparable data but also by the lack of sufficient understanding of marital and inheritance regimes. That which is available suggests that given women's disadvantage in the labour force, women fare better under community property than under separation of property regimes. However, a view of the complete picture requires a combined analysis of marital and inheritance regimes. It will be up to future empirical work to demonstrate how particular combinations of marital and inheritance regimes and social norms play out to favour or discourage the attainment of gender equality in wealth. In addition, to understand the patterns of wealth transmission across generations, it is important to consider both inter vivos transfers and bequests. Finally, household structure, especially marital status and parenthood, are important determinants of wealth. 
Methodological issues will continue to be a challenge. The best estimates of the division of wealth by gender come from probate records, but when available, they are biased toward the wealthy. Large-scale datasets ignore the individual wealth of spouses and the property rights governing the marriage. In addition, studies frequently do not consider all of the components of wealth; such studies look at pensions, land, or financial assets, but not all of them together. Given the fragmentary and incomplete nature of the data, it is premature to draw conclusions regarding general trends in the gender patterns of asset ownership. The available evidence nonetheless suggests that in developed countries nineteenth century policy reforms contributed substantially to reducing the gender asset gap, and that in countries such as the US and UK the gender gap is largest among the super rich (Deere and Doss 2006). For less developed countries, it appears that the gender asset gap will not decrease without strong, effective policy interventions.

As detailed analysis of Latin America and Africa shows, there are formidable constraints to increasing women's access to assets, particularly land. While the legal systems are changing to improve women's legal access to land, the interaction of legal rights and social norms still limits women's access to land. Not only is it important to study the actual patterns of land ownership by gender, but it will be critical to understand how women's access to land increases or decreases due to broader societal and policy factors, including land titling programs, changes in the legal system, increased value of land and agricultural products, and nonagricultural opportunities. Women's ability to organize around land issues in various settings will affect the gender land gap as well.

There are a number of directions for future research on women and wealth. Better data collection would allow us to better answer the question of what wealth women already own. It would also allow us to understand the various gendered patterns of asset ownership, including what types of assets are commonly accumulated by men and women. Additional work is needed to conceptualize wealth within households and detailed ethnographic studies from a variety of contexts would help in this respect. Incorporation of gender into a broader range of studies of the distribution of wealth will be an important first step.

\section{References}

Adams, M. (2003). 'Land Tenure Policy and Practice in Botswana: Governance Lessons for Southern Africa', Austrian Journal of Development Studies 29(1): 55-74

Agarwal, B. (1994). A Field of One’s Own, Cambridge University Press: Cambridge.

Agarwal, B. (1997). 'Bargaining and Gender Relations: Within and Beyond the Household', Feminist Economics 3(1): 1-51. 
Antonopoulos, R., and M.S. Floro (2005). 'Asset Ownership along Gender Lines: Evidence from Thailand', Gender, Equality, and the Economy Working Paper 418, Levy Economics Institute: Annandale-on-Hudson NY.

Beegle, K., E. Frankenberg, and D. Thomas (2001). 'Bargaining Power within Couples and Use of Prenatal and Delivery Care in Indonesia', Studies in Family Planning 32(2): 130-46.

Breza, E. (2005). 'Intrahousehold Resource Allocation in Hausa-speaking Nigeria: Uncovering Gender Assymmetries of Wealth and Savings Behavior', mimeo, Yale University Economics Department: New Haven CT.

Datta, N. (2006). 'Joint Titling: A Win-Win Policy? Gender and Property Rights in Urban Informal Settlements in Chandigarh, India', Feminist Economics 12(1 \& 2): 271-98.

Deere, C.D., and M. León (2001a). Empowering Women: Land and Property Rights in Latin America, University of Pittsburgh Press: Pittsburgh.

Deere, C.D., and M. León (2001b). 'Who Owns the Land? Gender and Land-Titling Programmes in Latin America’, Journal of Agrarian Change 1(3): 440-67.

Deere, C.D., and M. León (2003). 'The Gender Asset Gap: Land in Latin America', World Development 31(6): 925-47.

Deere, C.D., and M. León (2005). ‘The Impact of Liberalism on Married Women’s Property Rights in Nineteenth Century Latin America', Hispanic American Historical Review 85(4): 627-78.

Deere, C.D., R.L. Duran, M. Mardon, T. Masterson with M. Correia (2005). 'Women’s Land Rights and Rural Household Incomes in Brazil, Paraguay and Peru', Agriculture and Rural Development Internal Report, World Bank: Washington DC.

Deere, C.D., and C. Doss (2006). 'Introduction. The Gender Asset Gap: What Do We Know and Why Does It Matter?’, Feminist Economics 12(1 \& 2): 1-50.

Doss, C.R. (2006a). 'The Effects of Intrahousehold Property Ownership on Expenditure Patterns in Ghana', Journal of African Economies 15: 149-80.

Doss, C.R. (2006b). 'Women and Land in Ghana', paper presented at the meeting of the International Association of Feminist Economics, Sydney, Australia, July.

Duflo, E. (2000). 'Grandmothers and Granddaughters: Old-Age Pension and Intrahousehold Allocation in South Africa', mimeo, Department of Economics, Massachusetts Institute of Technology: Cambridge MA.

Esposito, J.L., with N.J. De Long-Bas (2001). Women in Muslim Family Law, University of Syracuse Press: Syracuse. 
Fafchamps, M., and A.R. Quisumbing (2002). 'Control and Ownership of Assets Within Rural Ethiopian Households’, Journal of Development Studies 38(6): 47-82.

FAO (1997). Women and Population Division. Women: The Key to Food Security, www.fao.org/documents/show_cdr.asp?url_file=/docrep/X0171E/X0171E00.htm (accessed 28.3.2006).

Fay, M.A. (1998). 'From Concubines to Capitalists: Women, Property, and Power in Eighteenth-Century Cairo’, Journal of Women's History 10(3): 118-40.

Fenrich, J., and T.E. Higgins (2002). 'Promise Unfulfilled: Law, Culture and Women's Inheritance Rights in Ghana’, Fordham International Law Journal 25: 259-341.

Friedemann-Sánchez, G. (2006). 'Assets in Intrahousehold Bargaining among Women Workers in Colombia’s Cut-Flower Industry’, Feminist Economics 12(1 \& 2): 247-69.

Goldstein, M., and C. Udry (2005). 'The Profits of Power: Land Rights and Agricultural Investment in Ghana', mimeo, Economic Growth Center, Yale University: New Haven CT.

Gray, L., and M. Kevane (1999). 'Diminished Access, Diverted Exclusion: Women and Land Tenure in Sub-Saharan Africa', African Studies Review 42(2): 15-39.

Human Rights Watch (2003). 'Double Standards: Women’s Property Rights Violations in Kenya', Human Rights Watch 15(5A).

ICRW (2005). 'Property Ownership for Women Enriches Empowers and Protects', Policy Brief, International Center for Research on Women: Washington DC.

Ikdahl, I., et al. (2005). 'Human Rights, Formalization, and Women's Land Rights in Southern and Eastern Africa', Studies in Women's Law 57, Institute of Women's Law: University of Oslo.

Katz, E., and J. Chamorro (2003). 'Gender, Land Rights, and the Household Economy in Rural Nicaragua and Honduras', paper presented at the annual conference of the Latin American and Caribbean Economics Association, Puebla, Mexico, October.

Mardon, M. (2005). 'Three Essays on Gender, Land Rights and Collective Action in Brazil’s Rural Political Economy', PhD dissertation, Economics Department, University of Massachusetts: Amherst.

Meinzen-Dick, R.S., L.R. Brown, H.S. Feldstein, and A.R. Quisumbing (1997). 'Gender, Property Rights, and Natural Resources', World Development 25(8): 1303-15.

Munalula, M., and W. Mwenda (1995). 'Case Study: Women and Inheritance Law in Zambia', in M. Hay and S. Stichter (eds) African Women: South of the Sahara, Longman Scientific and Technical: New York.

Nazarri, M. (1991). Disappearance of the Dowry: Women, Families, and Social Change in Sao Paulo, Brazil (1600-1900), Stanford University Press: Stanford. 
Okore, M. (2006). 'Land Act Has No Legal Consequence: Baguma', New Vision (Kampala) 4 February.

Panda, P., and B. Agarwal (2005). 'Marital Violence, Human Development, and Women's Property Status in India', World Development 33(5): 823-50.

Platteau, J.-P., and J.-M. Baland (2001). 'Impartible Inheritance versus Equal Division: A Comparative Perspective Centered on Europe and sub-Saharan Africa', in A. de Janvry, G. Gordillo, J.-P. Platteau, and E. Sadoulet (eds) Access to Land, Rural Poverty, and Public Action, Oxford University Press for UNU-WIDER: Oxford.

Quisumbing, A.R., and J. Maluccio (2003). 'Resources at Marriage and Intrahousehold Allocation: Evidence from Bangladesh, Ethiopia, Indonesia, and South Africa', Oxford Bulletin of Economics and Statistics 65: 283-327.

Quisumbing, A.R., and K. Hallman (2003). 'Marriage in Transition: Evidence on Age, Education, and Assets from Six Developing Countries', Policy Research Division Working Paper 183, Population Council: New York.

Rao, S. (2005). 'Gender, Liberalization and Agrarian Change in Telangana, India', PhD dissertation, Economics Department, University of Massachusetts: Amherst.

Rocheleau, D., and D. Edmunds (1997). 'Women, Men, and Trees: Gender, Power, and Property in Forest and Agrarian Landscapes’, World Development 25(8): 1351-71.

Roth, M. (2002). 'Integrating Land Issues and Land Policy with Poverty Reduction and Rural Development in Southern Africa', paper prepared for the World Bank Regional Workshop on Land Issues in Africa and the Middle East, Kampala, Uganda, April.

Rugadya, M., E. Obaikol, and K. Herbert (2005). Critical Pastoral Issues and Policy Statements for the National Land Policy in Uganda, Associates for Development: Kampala.

Shammas, C., M. Salmon, and M. Dahlin (1987). Inheritance in America, from Colonial Times to the Present, Rutgers University Press: New Brunswick.

Shawa, M. (2002). Gender Implications of the National Land Policy', paper presented at the National Civil Society Meeting on Land Reform Policy, Blanytre, Malawi, March.

Strickland, R.S. (2004). To Have and To Hold: Women's Property and Inheritance Rights in the Context of HIV/AIDS in sub-Saharan Africa, International Center for Resarch on Women: Washington DC.

Tekle, T. (2001). 'Women's Access to Land and Property Rights in Eritrea', in Women's Land and Property Rights in Situations of Conflict and Reconstruction: Towards Good Practice', United Nations Development Fund for Women, a reader based on the February 1998 Inter-Regional Consultation in Kigali, Rwanda. 
Teklu, A. (2005). 'Land Registration and Women’s Land Rights in Amhara Region, Ethiopia', Securing Land Rights in Africa Research Report 4, International Institute for Environment and Development: London.

Thomas, D. (1999). 'Intrahousehold Resource Allocation: An Inferential Approach', Journal of Human Resources 25(4): 635-64.

United Nations (1980). Convention on the Elimination of All Forms of Discrimination against Women, United Nations: New York.

Walker, C. (2002). Land Reform in Southern and Eastern Africa: Key Issues for Strengthening Women's Access To and Rights in Land, FAO: Rome

World Bank (2001). Engendering Development, World Bank: Washington DC.

Yngstrom, I. (2002). 'Women, Wives, and Land Rights in Africa: Situating Gender Beyond the Household in the Debate Over Land Policy and Changing Tenure Systems’, Oxford Development Studies 30:21-40. 